\section{Experimental infection of commercial layers using a Salmonella enterica serovar Gallinarum strain: Leukogram and serum acute-phase protein concentrations}

\section{ABSTRACT}

The aim of the present study was to evaluate white blood cell counts and serum protein profiles of commercial layers experimentally infected with Salmonella Gallinarum (SG) in order to better understand the pathophysiology of the disease caused by this bacterium. 180 five-dayold commercial layers were divided into 3 groups $(\mathrm{G}) ; \mathrm{G} 1$ and $\mathrm{G} 2$ received $0.2 \mathrm{~mL}$ of inoculate containing $3.3 \times 10^{8}$ CFU or $3.3 \times 10^{5}$ CFU SG resistant to nalidix acid $\left(\mathrm{Nal} \mathrm{l}^{\mathrm{r}} / \mathrm{mL}\right.$, respectively, directly into their crops. $\mathrm{G} 3$ group did not receive the inoculum. Birds were sacrificed 24 hours before (T1) and 24 hours after the infection (T2), and three (T3), five (T4), seven (T5), and ten (T6) days after the administration of the inoculum. White blood cell counts were carried out in a Neubauer hemocytometer and in blood smears. Serum protein concentrations, including acute-phase proteins, were determined using sodium dodecyl sulphatepolyacrylamide gel electrophoresis (SDS-PAGE). Data were submitted to analysis of variance, and means were compared by Tukey's test ( $P$ $<0.05)$. G1 and G2 groups presented higher leukocyte counts on T4 and $T 5$, respectively, due to the increase of circulating lymphocytes and heterophils, with a significant difference relative to G3. In electrophoresis, an increase in the serum levels of ceruloplasmin, haptoglobin, and hemopexin and a decrease in transferrin, which are acute-phase proteins, was verified. IgA serum levels did not change; however, IgG concentration increased during the infection. In conclusion, the results provide information for the better understanding of the pathophysiology of fowl typhoid.

\section{INTRODUCTION}

Fowl typhoid, caused by Salmonella enterica serovar Gallinarum or, simply, Salmonella Gallinarum, is a severe systemic disease that affects commercial poultry and other galliform species. When it infects a poultry farm, it causes relevant economic losses due to high morbidity and mortality rates, as well as egg production reduction. It is worldwide distributed, and it is generally regarded as a developing-country disease, including Central America, South America, Africa and Asia (Berchieri Jr., 2000).

The study of leukocyte response and of the kinetics of acute-phase proteins and immunoglobulins is essential for the understanding of the pathophysiology of different infectious diseases. Therefore, the study of epidemiologically relevant infectious processes in poultry, such as fowl typhoid, is essential, particularly because there are few studies on this subject. Sodium dodecyl sulphate-polyacrylamide gel electrophoresis (SDS-PAGE) is very useful for the evaluation of acute-phase protein serum concentrations during the acute phase of infections, as well as of immunoglobulin levels. 
Garcia KO, Berchieri-Júnior A, Santana AM, Freitas-Neto OC, Fagliari JJ
The aim of this study was to evaluate white blood cell counts and acute-phase protein serum concentrations of commercial layers experimentally infected with Salmonella Gallinarum, in order to have a better understanding of the evolution of the disease.

\section{MATERIAL AND METHODS}

\section{Birds and housing}

A number of 180 commercial semi-heavy (brown) layers, considered susceptible to the infection by Salmonella Gallinarum was used. Blood samples were collected at arrival at the experimental facilities for the serological test (fast serum agglutination test using a commercial Salmonella Pullorum antigen). Fecal swabs were taken from the transport crate for the bacteriological detection of Salmonella, in order to ensure that birds were free from pathogens that might compromise the experiment (Zancan et al., 2000). The results showed that all birds were negative for Salmonella Gallinarum. Birds were then divided into three groups ( $G 1, G 2$, and $G 3$ ) of sixty individuals each, and housed in battery cages, located at the isolation units of the Laboratory of Veterinary Pathology of the Department of Veterinary Pathology, Faculdade de Ciências Agrárias e Veterinárias, Universidade Estadual Paulista (FCAVJ-UNESP), Brazil. Birds received water and food ad libitum.

\section{Preparation of the inoculum}

A nalidixic-acid resistant Salmonella Gallinarum strain (SGNalr), was used, as recommended by Berchieri Jr. et al. (2001). The strain was prepared and kept at the Department of Veterinary Pathology (FCAVJUNESP). The bacterium was cultivated in nutrient broth (Difco-244620), incubated in a shaking incubator (100 strokes $/ \mathrm{min}$ ) at $37^{\circ} \mathrm{C}$, for $24 \mathrm{~h}$. Cultures were prepared in two different dilutions: one with approximately $3.3 \times 10^{8} \mathrm{CFU}$ of S. Gallinarum Nalr $/ \mathrm{mL}$ and another with $3.3 \times 10^{5} \mathrm{CFU}$ of S. Gallinarum Nalr/mL.

\section{Experimental procedure}

$\mathrm{G} 1$ and $\mathrm{G} 2$ birds received $0.2 \mathrm{~mL}$ of an inoculum containing $3.3 \times 10^{8}$ or $3.3 \times 10^{5}$ CFU of Salmonella Gallinarum, respectively, directly into the crop using a cannula. G3 birds did not receive any inoculum (control group). All birds were challenged at 5 days of age and sacrificed to obtain blood samples. Euthanasia was carried out (ten birds at a time in each group) $24 \mathrm{~h}$ before (T1) or after (T2) the infection, and 3(T3), 5(T4), 7(T5), or 10 (T6) days after infection.
Experimental infection of commercial layers using a Salmonella enterica serovar Gallinarum strain: Leukogram and serum acute-phase protein concentrations

\section{Clinical evaluation}

Birds were submitted to a physical examination twice daily - in the morning and afternoon - and, in the case of death, mortality was recorded, as described by Oliveira et al. (2005).

\section{Blood collection and laboratory analysis}

Birds were rendered unconscious, and then submitted to euthanasia. Blood samples were collected from the cervical vein. Blood samples for white blood cell counts were collected in tubes containing 10\% EDTA. Blood samples for the serum protein profile were collected in tubes with no anticoagulant.

\section{White blood cell counts and serum protein electrophoresis (SDS-PAGE)}

White blood cell counts were carried out in a Neubauer hemocytometer (Natt \& Herrick, 1952). Blood smears were prepared for differential leukocyte count, and stained by the Rosenfeld method (Lucas \& Jamroz, 1961). Serum protein electrophoresis was carried out in sodium dodecyl sulfate acrylamide gel (SDS-PAGE), as proposed by Weber \& Osborn (1969). The gel was stained for 10 minutes in $0.25 \%$ Coomassie blue solution and then de-stained in $7 \%$ acetic acid, until protein fractions were clear. The concentrations of those proteins were determined in a scanning densitometer (Shimadzu CS9301, Tokyo). A marker solution with different molecular weights (Sigma S8445), as well as, purified ceruloplasmin, haptoglobin, antitrypsin, transferrin, and IgG proteins were used as references.

\section{Statistical analysis}

A completely randomized experimental design with in a $3 \times 6$ factorial arrangement (infection levels and pre and post-infection times) was used for statistical analysis. Data were submitted to analysis of variance using SAS statistical program, and means were compared by Tukey's test $(P<0.05)$.

\section{RESULTS}

\section{White blood cell count}

White blood cell counts (WBC) initially decrease (T2) in both infected groups ( $G 1$ and $G 2$ ) due to a reduction in lymphocyte and heterophil counts. From T3 on a recovery in the number of circulating leukocytes was observed in the two infected groups due an increase in lymphocyte and heterophil counts (Table 1 and Figure 1). G1, which were inoculated with higher bacterial 
Garcia KO, Berchieri-Júnior A, Santana AM, Freitas-Neto OC, Fagliari JJ
Experimental infection of commercial layers using a Salmonella enterica serovar Gallinarum strain: Leukogram and serum acute-phase protein concentrations

Table 1. Means and standard deviations of white blood cell counts $\left(\times 10^{3} / \mathrm{mL}\right)$ of brown layers experimentally infected with Salmonella Gallinarum Nalr

\begin{tabular}{|c|c|c|c|c|}
\hline \multirow[t]{2}{*}{ Parameters } & \multirow[t]{2}{*}{ Time } & \multicolumn{3}{|c|}{ Groups } \\
\hline & & 1 & 2 & 3 \\
\hline \multirow[t]{6}{*}{ Leukocytes (x103/mL) } & 1 & $13.5 \pm 1.04 \mathrm{ABa}$ & $13.5 \pm 1.17 \mathrm{ABa}$ & $11.91 \pm 1.46 \mathrm{Aa}$ \\
\hline & 2 & $8.33 \pm 0.83 \mathrm{Aa}$ & $8.42 \pm 1.01 \mathrm{Aa}$ & $10.48 \pm 1.28 \mathrm{Aa}$ \\
\hline & 3 & $15.7 \pm 3.81 \mathrm{ABa}$ & $11.5 \pm 0.70 \mathrm{Aa}$ & $10.26 \pm 1.55 \mathrm{Aa}$ \\
\hline & 4 & $56.8 \pm 7.46 \mathrm{Ca}$ & $9.69 \pm 1.41 \mathrm{Ab}$ & $11.07 \pm 1.18 \mathrm{Ab}$ \\
\hline & 5 & $27.7 \pm 2.65 \mathrm{Ba}$ & $18.8 \pm 1.37 \mathrm{Bb}$ & $10.75 \pm 1.28 \mathrm{Ab}$ \\
\hline & 6 & * & $18.6 \pm 2.08 \mathrm{Bb}$ & $9.48 \pm 1.33 \mathrm{Aa}$ \\
\hline \multirow[t]{6}{*}{ Heterophils $\left(\times 10^{3} / \mathrm{mL}\right)$} & 1 & $4.56 \pm 0.75 \mathrm{Aa}$ & $4.88 \pm 0.88 \mathrm{ABa}$ & $4.07 \pm 0.64 \mathrm{Aa}$ \\
\hline & 2 & $3.16 \pm 0.63 \mathrm{Aa}$ & $3.56 \pm 0.69 \mathrm{Aa}$ & $3.89 \pm 0.70 \mathrm{Aa}$ \\
\hline & 3 & $6.86 \pm 0.97 \mathrm{Bb}$ & $5.37 \pm 1.05 \mathrm{Bb}$ & $3.44 \pm 0.49 \mathrm{Aa}$ \\
\hline & 4 & $28.96 \pm 3.45 \mathrm{Db}$ & $5.04 \pm 0.98 \mathrm{Ba}$ & $3.84 \pm 0.61 \mathrm{Aa}$ \\
\hline & 5 & $17.78 \pm 1.35 \mathrm{Cc}$ & $10.34 \pm 2.15 \mathrm{Cb}$ & $3.87 \pm 0.80 \mathrm{Aa}$ \\
\hline & 6 & * & $8.55 \pm 2.33 \mathrm{BCb}$ & $3.55 \pm 0.55 \mathrm{Aa}$ \\
\hline \multirow[t]{6}{*}{ Lymphocytes (x 103/mL) } & 1 & $8.85 \pm 1.20 \mathrm{Ba}$ & $8.69 \pm 1.66 \mathrm{Ba}$ & $7.40 \pm 1.32 \mathrm{Aa}$ \\
\hline & 2 & $5.08 \pm 1.05 \mathrm{Aa}$ & $4.82 \pm 0.75 \mathrm{Aa}$ & $6.36 \pm 1.40 \mathrm{Aa}$ \\
\hline & 3 & $8.48 \pm 1.78 \mathrm{Ba}$ & $6.00 \pm 1.13 \mathrm{ABa}$ & $6.29 \pm 1.23 \mathrm{Aa}$ \\
\hline & 4 & $26.35 \pm 4.25 \mathrm{Cb}$ & $4.38 \pm 1.01 \mathrm{Aa}$ & $6.59 \pm 1.75 \mathrm{Aa}$ \\
\hline & 5 & $9.14 \pm 1.93 \mathrm{Bb}$ & $8.04 \pm 1.23 \mathrm{Bab}$ & $6.48 \pm 1.12 \mathrm{Aa}$ \\
\hline & 6 & * & $9.75 \pm 2.04 \mathrm{Bb}$ & $5.55 \pm 1.35 \mathrm{Aa}$ \\
\hline \multirow[t]{6}{*}{ Monocytes (x 103/mL) } & 1 & $0.30 \pm 0.10 \mathrm{BCb}$ & $0.13 \pm 0.04 \mathrm{ABa}$ & $0.29 \pm 0.13 \mathrm{Ab}$ \\
\hline & 2 & $0.09 \pm 0.04 \mathrm{Aa}$ & $0.07 \pm 0.03 \mathrm{Aa}$ & $0.28 \pm 0.15 \mathrm{Ab}$ \\
\hline & 3 & $0.20 \pm 0.07 \mathrm{ABab}$ & $0.11 \pm 0.04 \mathrm{Aba}$ & $0.25 \pm 0.08 \mathrm{Ab}$ \\
\hline & 4 & $0.79 \pm 0.27 \mathrm{DC}$ & $0.12 \pm 0.05 \mathrm{ABa}$ & $0.28 \pm 0.11 \mathrm{Ab}$ \\
\hline & 5 & $0.50 \pm 0.16 \mathrm{Cb}$ & $0.22 \pm 0.11 \mathrm{Ba}$ & $0.30 \pm 0.12 \mathrm{Aa}$ \\
\hline & 6 & * & $0.23 \pm 0.09 \mathrm{Ba}$ & $0.24 \pm 0.09 \mathrm{Aa}$ \\
\hline
\end{tabular}

* = High mortality. Means followed by different capital letters in the same column or by different small letters in the same row are significantly different by Tukey's test $(P<0.05)$
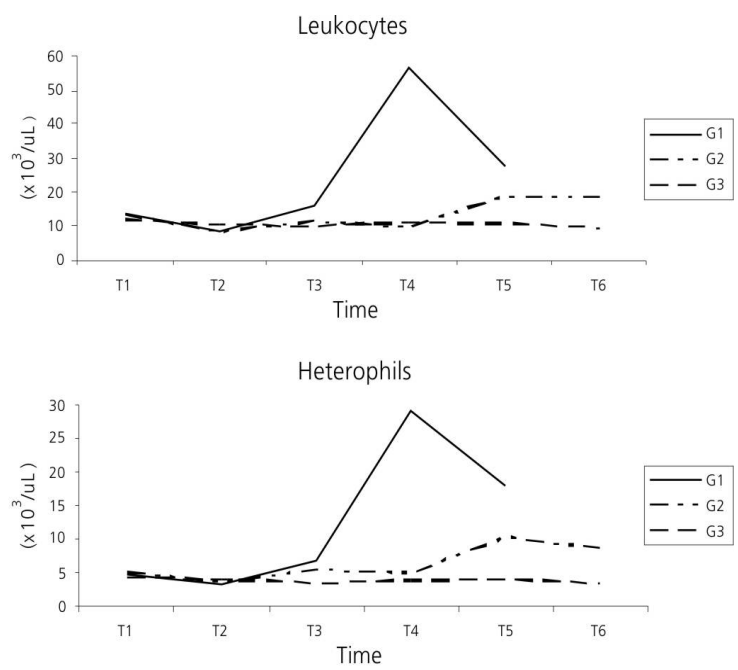

Lymphocytes

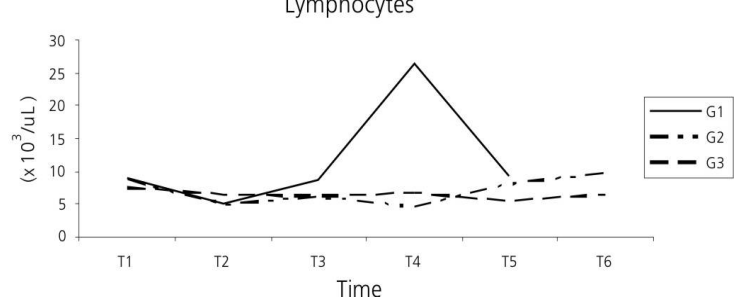

Figure 1. Means leukocyte, heterophil, and lymphocyte counts in group 1 (G1), group $2(\mathrm{G} 2)$, and group $3(\mathrm{G} 3)$ of brown layers experimentally infected with $S$. Gallinarum $\mathrm{Nal}^{\prime} 24$ hours before (T1) and 24 hours after inoculation (T2), and three (T3), five (T4), seven (T5), and ten (T6) days after inoculation. concentration, presented evident leukocytosis at T4, characterized by an increase in lymphocyte and heterophil counts, with a high proportional increase of heterophils, leading to an inversion of the heterophil:lymphocyte ratio. After a high WBC count at T4, leukocyte count was reduced at T5, due to a decrease in heterophil and lymphocyte counts; however, these not returned to basal values (Table 1 and Figure 1). In G2, which were inoculated with a lower bacterial concentration, leukocytosis was observed at T5 due to an increase not only of lymphocytes but also of heterophils, resulting in high heterophil counts. WBC count remained the same at T6; however an inversion was observed in the heterophil:lymphocyte ratio due to a decrease in heterophil count and an increase in lymphocyte counts (Table 1 and Figure 1).

\section{Serum protein concentrations}

Ten proteins were studied using the SDS-PAGE technique. Their molecular weights (MW) ranged from 32 to $171 \mathrm{Kd}$ (Table 2): IgA, ceruloplasmin, transferrin, hemopexin, albumin, heavy chain IgG, haptoglobin, light chain lgG, and proteins with $96 \mathrm{Kd}$ and $171 \mathrm{Kd}$ molecular weight.

Serum concentrations of acute-phase ceruloplasmin, hemopexin and haptoglobin proteins were higher in 
Table 2. Means and standard deviations of total protein serum levels $(\mathrm{g} / \mathrm{dL})$ and protein fractions (mg/dL) obtained by sodium dodecyl sulphate-polyacrylamide gel electrophoresis (SDS-PAGE) in brown layers experimentally infected with Salmonella Gallinarum Nalr.

\begin{tabular}{|c|c|c|c|c|c|c|}
\hline Protein & $\mathrm{T} 1$ & $\mathrm{~T} 2$ & T3 & T4 & T5 & T6 \\
\hline \multicolumn{7}{|c|}{ Total protein } \\
\hline G1 & $3.5 \pm 0.8 \mathrm{ABa}$ & $3.6 \pm 0.3 \mathrm{Aa}$ & $3.8 \pm 0.7 \mathrm{Aa}$ & $3.5 \pm 0.5 \mathrm{Aa}$ & $3.6 \pm 0.7 \mathrm{Aa}$ & * \\
\hline G2 & $4.1 \pm 0.5 \mathrm{ABa}$ & $3.5 \pm 0.9 \mathrm{BCa}$ & $3.1 \pm 0.5 \mathrm{Ca}$ & $3.2 \pm 0.9 \mathrm{Ca}$ & $3.3 \pm 0.8 \mathrm{Ca}$ & $3.1 \pm 0.8 \mathrm{Ca}$ \\
\hline G3 & $3.3 \pm 0.9 \mathrm{Aa}$ & $3.0 \pm 0.7 \mathrm{Aa}$ & $3.2 \pm 0.5 \mathrm{Aa}$ & $3.1 \pm 0.3 \mathrm{Aa}$ & $2.8 \pm 0.6 \mathrm{Aa}$ & $2.9 \pm 0.7 \mathrm{Aa}$ \\
\hline \multicolumn{7}{|l|}{$\operatorname{Ig} A$} \\
\hline G1 & $31.3 \pm 2.6 \mathrm{Aab}$ & $21.1 \pm 2.4 \mathrm{ABa}$ & $12.8 \pm 2.4 \mathrm{Ba}$ & $18.9 \pm 2.6 \mathrm{ABa}$ & $13 \pm 3.6 \mathrm{Ba}$ & * \\
\hline G2 & $41.3 \pm 2.7 \mathrm{Aa}$ & $20.7 \pm 2.4 \mathrm{Ba}$ & $17.5 \pm 2.4 \mathrm{BCa}$ & $14.9 \pm 2.4 \mathrm{BCa}$ & $11.2 \pm 2.6 \mathrm{Ca}$ & $20 \pm 2.6 \mathrm{BCa}$ \\
\hline G3 & $27.1 \pm 2.5 \mathrm{Ab}$ & $16.1 \pm 2.4 \mathrm{Aa}$ & $16 \pm 2.6 \mathrm{Aa}$ & $16.3 \pm 2.4 \mathrm{Aa}$ & $16 \pm 2.5 \mathrm{Aa}$ & $16.1 \pm 2.3 \mathrm{Aa}$ \\
\hline \multicolumn{7}{|c|}{$171 \mathrm{Kd}$ Protein } \\
\hline G1 & $55.6 \pm 8.8 \mathrm{Aa}$ & $72.6 \pm 8.5 \mathrm{Ba}$ & $78.0 \pm 7.6 \mathrm{Ba}$ & $48.4 \pm 6.9 \mathrm{Ca}$ & $50.8 \pm 8.4 \mathrm{Ca}$ & * \\
\hline G2 & $63.5 \pm 9.1 \mathrm{Aa}$ & $65.5 \pm 9.2 \mathrm{Aa}$ & $75.5 \pm 8.4 \mathrm{Ba}$ & $49.1 \pm 7.5 \mathrm{Ca}$ & $48.1 \pm 7.8 \mathrm{Ca}$ & $44.5 \pm 8.8 \mathrm{Aa}$ \\
\hline G3 & $53.6 \pm 8.7 \mathrm{Aa}$ & $51.6 \pm 7.5 \mathrm{Ab}$ & $52.5 \pm 8.9 \mathrm{Ab}$ & $51.3 \pm 9.5 \mathrm{Aa}$ & $52.7 \pm 8.9 \mathrm{Aa}$ & $48.8 \pm 9.9 \mathrm{Aa}$ \\
\hline \multicolumn{7}{|c|}{ Ceruloplasmin } \\
\hline G1 & $27.1 \pm 9.5 \mathrm{Aa}$ & $69.1 \pm 18.8 \mathrm{Ba}$ & $92.4 \pm 25.4 \mathrm{Ca}$ & $1099 \pm 5 \mathrm{Da}$ & $87.6 \pm 13.3 \mathrm{Ba}$ & * \\
\hline G2 & $34.5 \pm 10.1 \mathrm{Aa}$ & $59.1 \pm 17.6 \mathrm{Ba}$ & $81.5 \pm 20.1 \mathrm{Ca}$ & $71.8 \pm 9.8 \mathrm{Cb}$ & $62.9 \pm 9.4 \mathrm{Bb}$ & $63.6 \pm 9.4 \mathrm{Aa}$ \\
\hline G3 & $26.7 \pm 7.7 \mathrm{Aa}$ & $28.9 \pm 8.8 \mathrm{Ab}$ & $27.7 \pm 8.3 \mathrm{Ab}$ & $33.9 \pm 9.3 \mathrm{Ac}$ & $31.1 \pm 8.1 \mathrm{Ac}$ & $35.3 \pm 9.6 \mathrm{Ab}$ \\
\hline \multicolumn{7}{|c|}{96 Kd Protein } \\
\hline G 1 & $8.6 \pm 6.7 \mathrm{Aa}$ & $10.1 \pm 6.1 \mathrm{Aa}$ & $20.7 \pm 8.8 \mathrm{Ba}$ & $45.6 \pm 13.7 \mathrm{Ca}$ & $58.0 \pm 9.7 \mathrm{Ca}$ & * \\
\hline G2 & $10.8 \pm 7.1 \mathrm{Aa}$ & $11.7 \pm 6.2 \mathrm{Aa}$ & $17.2 \pm 6.0 \mathrm{Aa}$ & $27.6 \pm 6.2 \mathrm{Bb}$ & $37.7 \pm 8.6 \mathrm{Cab}$ & $37.5 \pm 9.7 \mathrm{Ca}$ \\
\hline G3 & $7.9 \pm 6.4 \mathrm{Aa}$ & $7.3 \pm 5.2 \mathrm{Aa}$ & $7.0 \pm 6.1 \mathrm{Ab}$ & $7.7 \pm 5.3 \mathrm{Ac}$ & $8.0 \pm 6.0 \mathrm{Ac}$ & $7.0 \pm 5.1 \mathrm{Ab}$ \\
\hline \multicolumn{7}{|c|}{ Transferrin } \\
\hline G1 & $354 \pm 38.8 \mathrm{Aa}$ & $279 \pm 37.1 \mathrm{Ba}$ & $251 \pm 45.1 \mathrm{Ba}$ & $259 \pm 38.8 \mathrm{Ba}$ & $279 \pm 44.3 \mathrm{Ba}$ & * \\
\hline G2 & $361 \pm 41.0 \mathrm{Aa}$ & $246 \pm 33.9 \mathrm{Ba}$ & $248 \pm 37.6 \mathrm{Ba}$ & $270 \pm 45.1 \mathrm{BCa}$ & $290 \pm 38.3 \mathrm{Ca}$ & $322 \pm 38.3 \mathrm{Aa}$ \\
\hline G3 & $337 \pm 34.6 \mathrm{Aa}$ & $322 \pm 37.9 \mathrm{Ab}$ & $333 \pm 37.2 \mathrm{Ab}$ & $328 \pm 42.4 \mathrm{Ab}$ & $329 \pm 32.9 \mathrm{Aa}$ & $341 \pm 45.6 \mathrm{Aa}$ \\
\hline \multicolumn{7}{|c|}{ Hemopexin } \\
\hline G1 & $106 \pm 13.4 \mathrm{Aa}$ & $110 \pm 15.5 \mathrm{Aa}$ & $127 \pm 12.4 \mathrm{Ba}$ & $133 \pm 13.4 \mathrm{Ba}$ & $121 \pm 19.0 \mathrm{Ba}$ & * \\
\hline $\mathrm{G} 2$ & $117 \pm 14.3 \mathrm{Aa}$ & $118 \pm 13.3 \mathrm{Aa}$ & $123 \pm 12.4 \mathrm{ABa}$ & $135 \pm 13.3 \mathrm{Ba}$ & $130 \pm 14.2 \mathrm{Ba}$ & $128 \pm 14.2 \mathrm{Ba}$ \\
\hline G3 & $109 \pm 21.3 \mathrm{Aa}$ & $103 \pm 20.4 \mathrm{Aa}$ & $111 \pm 20.7 \mathrm{Ab}$ & $107 \pm 23.4 \mathrm{Ab}$ & $115 \pm 18.7 \mathrm{Ab}$ & $119 \pm 19.3 \mathrm{Aa}$ \\
\hline \multicolumn{7}{|c|}{ Albumin } \\
\hline G1 & $2.152 \pm 100 \mathrm{Aa}$ & $2.103 \pm 98 \mathrm{ABa}$ & $2.058 \pm 103 \mathrm{Ba}$ & $1.987 \pm 100 \mathrm{Ba}$ & $2.069 \pm 140 \mathrm{Ba}$ & * \\
\hline $\mathrm{G} 2$ & $2.299 \pm 106 \mathrm{Aa}$ & $2.165 \pm 105 \mathrm{Aa}$ & $2.172 \pm 95 \mathrm{Aa}$ & $2.021 \pm 106 \mathrm{Ba}$ & $2.069 \pm 99 \mathrm{Ba}$ & $2.017 \pm 99.1 \mathrm{Ba}$ \\
\hline G3 & $2.201 \pm 99 \mathrm{Aa}$ & $2.149 \pm 88 \mathrm{Aa}$ & $2.107 \pm 93 \mathrm{Aa}$ & $2.098 \pm 97 \mathrm{Aa}$ & $2.203 \pm 78 \mathrm{Aa}$ & $2.117 \pm 105 \mathrm{Aa}$ \\
\hline \multicolumn{7}{|c|}{ Heavy chain IqG } \\
\hline G1 & $132 \pm 18.4 \mathrm{Aa}$ & $141 \pm 18.3 \mathrm{Aa}$ & $168.4 \pm 19.7 \mathrm{Ba}$ & $194 \pm 28.4 \mathrm{Ca}$ & $224 \pm 21.8 \mathrm{Da}$ & * \\
\hline G2 & $142 \pm 19.0 \mathrm{Aa}$ & $155 \pm 22.0 \mathrm{Aa}$ & $166 \pm 23.4 \mathrm{Aa}$ & $190 \pm 17.8 \mathrm{Ba}$ & $207 \pm 23.5 \mathrm{Ba}$ & $249 \pm 10.7 \mathrm{Ca}$ \\
\hline G3 & $131 \pm 19.9 \mathrm{Aa}$ & $135 \pm 17.8 \mathrm{Aa}$ & $133 \pm 18.7 \mathrm{Ab}$ & $140 \pm 17.8 \mathrm{Ab}$ & $138 \pm 19.1 \mathrm{Ab}$ & $140 \pm 9.1 \mathrm{Ab}$ \\
\hline \multicolumn{7}{|c|}{ Haptoglobin } \\
\hline G1 & $9.2 \pm 3.4 \mathrm{Aa}$ & $14.6 \pm 6.7 \mathrm{Ba}$ & $25.9 \pm 5.4 \mathrm{Ca}$ & $47.4 \pm 8.6 \mathrm{Da}$ & $88.5 \pm 10.9 \mathrm{Ea}$ & * \\
\hline G2 & $8.0 \pm 3.5 \mathrm{Aa}$ & $10.0 \pm 4.6 \mathrm{Aa}$ & $19.5 \pm 8.6 \mathrm{Ba}$ & $35.1 \pm 12.3 \mathrm{Ca}$ & $64.6 \pm 13.9 \mathrm{Da}$ & $66.8 \pm 2.0 \mathrm{Da}$ \\
\hline G3 & $8.0 \pm 3.2 \mathrm{Aa}$ & $9.0 \pm 2.9 \mathrm{Aa}$ & $9.3 \pm 2.5 \mathrm{Ab}$ & $9.9 \pm 3.1 \mathrm{Ab}$ & $10.1 \pm 2.2 \mathrm{Ab}$ & $10.3 \pm 2.8 \mathrm{Ab}$ \\
\hline \multicolumn{7}{|c|}{ Light chain IgG } \\
\hline G 1 & $208 \pm 37.8 \mathrm{Aa}$ & $215 \pm 47.2 \mathrm{Aa}$ & $253 \pm 30.1 \mathrm{Ba}$ & $259 \pm 37.8 \mathrm{Ba}$ & $254 \pm 40.9 \mathrm{Ba}$ & * \\
\hline G2 & $224 \pm 28.3 \mathrm{Aa}$ & $220 \pm 27.2 \mathrm{Aa}$ & $256 \pm 27.9 \mathrm{Ba}$ & $247 \pm 30.2 \mathrm{Ba}$ & $259 \pm 32.6 \mathrm{Ba}$ & $250 \pm 40.1 \mathrm{Ba}$ \\
\hline G3 & $228 \pm 20.1 \mathrm{Aa}$ & $231 \pm 27.2 \mathrm{Aa}$ & $224 \pm 21.2 \mathrm{Aa}$ & $225 \pm 23.4 \mathrm{Aa}$ & $235 \pm 25.6 \mathrm{Aa}$ & $227 \pm 22.8 \mathrm{Aa}$ \\
\hline
\end{tabular}

* $=$ High mortality. Means followed by different capital letters in the same column or by different small letters in the same row are significantly different by Tukey's test $(P<0.05)$.

the inoculated groups ( $G 1$ and $G 2$ ) (Table 2) as compared to the control group. The kinetics of these acute phase proteins were different in $\mathrm{G} 1$ and in $\mathrm{G} 2$, with a strong initial increase in ceruloplasmin, followed by that of haptoglobin and of hemopexin. In the most advanced phases of the infection, a progressive decrease of the serum ceruloplasmin and hemopexin concentrations was observed, in contrast with haptoglobin, wich progressively increased during the entire course of the infection. As to the negative acutephase transferrin and albumin proteins, it was observed that serum transferrin levels in both infected groups decreased after the infection, recovering at $\mathrm{T} 4$.
However, even after the recovery, transferrin serum concentrations continued to be lower than those of the control group (Table 2 and Figure 2). In terms of immunoglobulins, the highest IgA concentrations were found in the infected groups prior to infection (T1). At $\mathrm{T} 2$, serum IgA concentrations decreased, and remained constant throughout the course of the disease, presenting similar values those of the control group. A significant increase, starting at $T 2$, in serum $\lg G$ concentrations was verified in the infected groups, and heavy chain $\lg G$ presented a proportionally higher increase (Table 2 and Figure 3). 

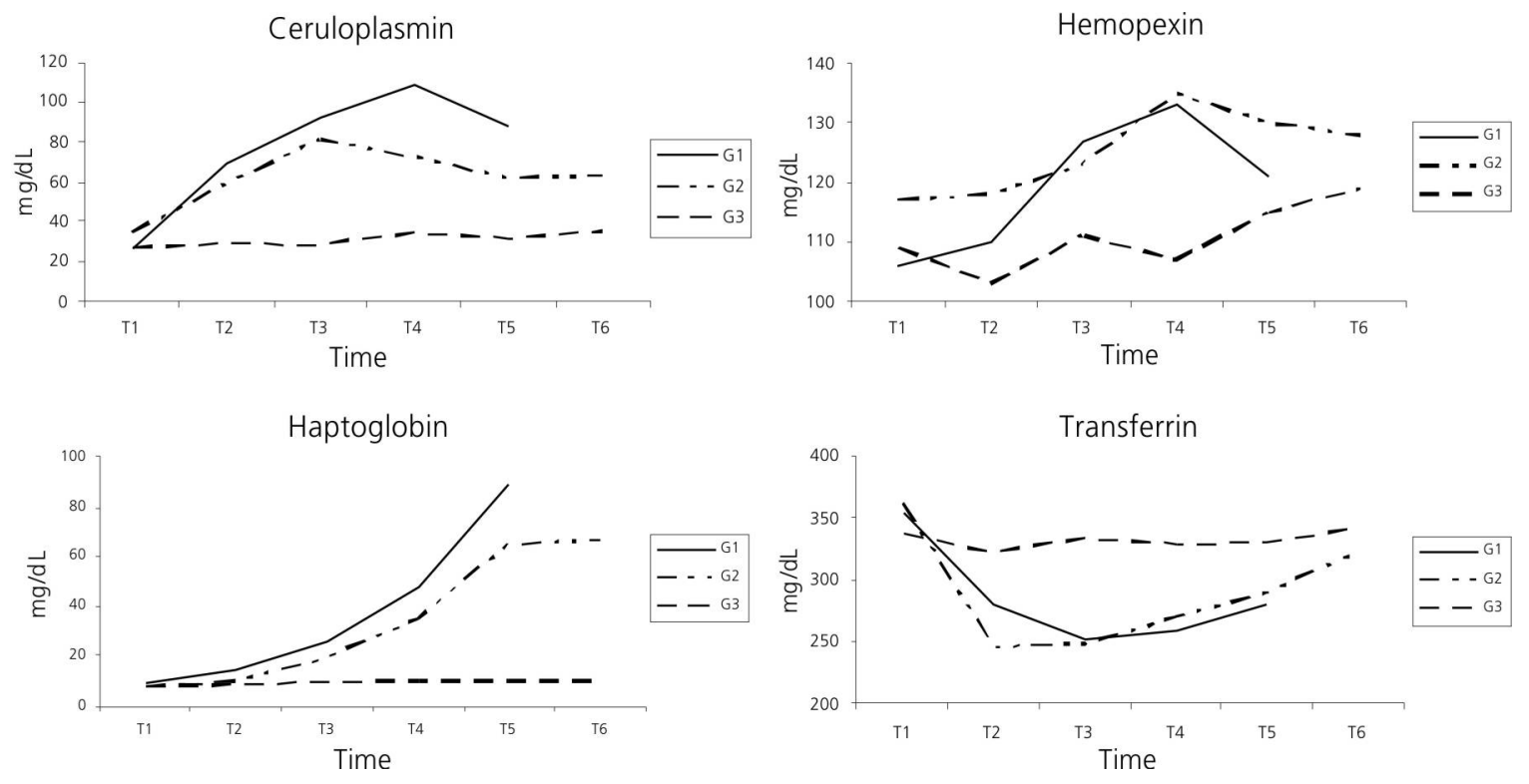

Figure 2. Ceruloplasmin, hemopexin, haptoglobin, and transferring mean serum concentrations in brown layers in group 1 (G1), group 2 (G2), and group 3 (G3) experimentally infected with S. Gallinarum Nal' 24 hours before (T1) and 24 hours after inoculation (T2), and three (T3), five (T4), seven (T5) and ten (T6) days after inoculation.
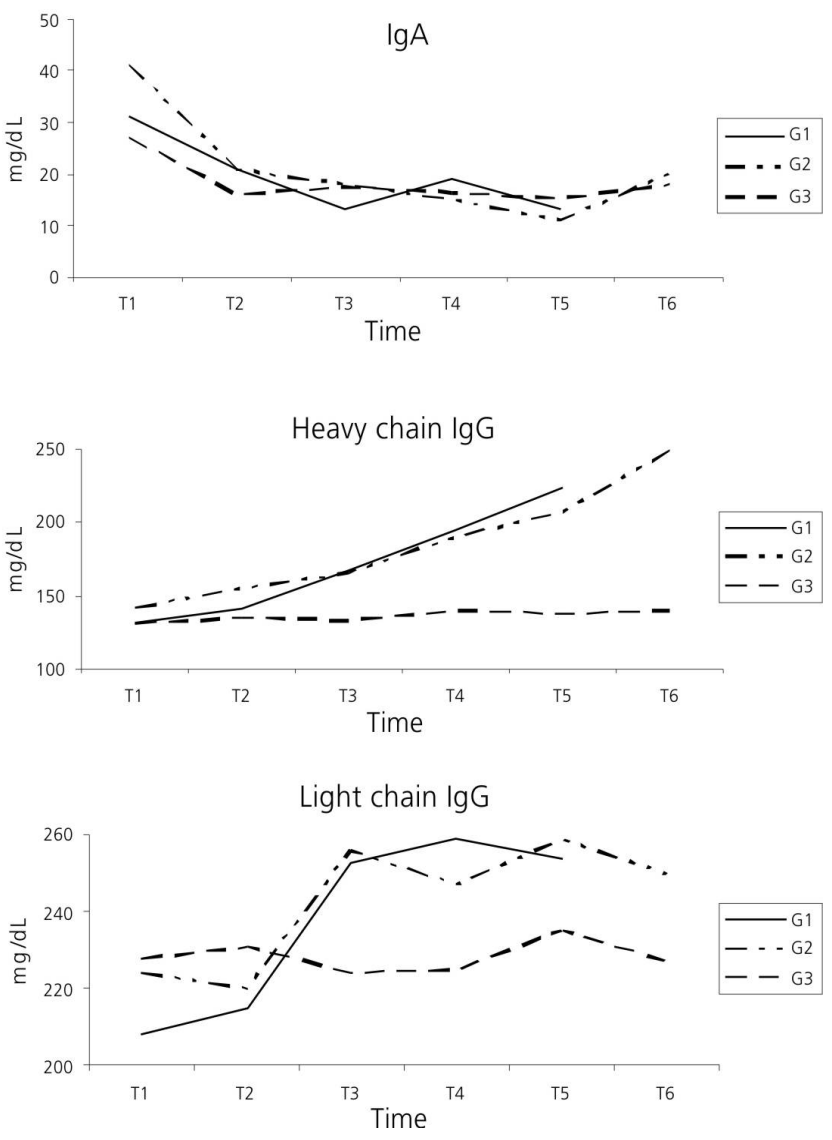

Figure 3. Heavy- and light-chain $\lg G$ and $\lg A$ serum concentrations in brown layers in group 1 (G1), group 2 (G2), and group 3 (G3) experimentally infected with $S$. Gallinarum Nal' 24 hours before (T1) and 24 hours after inoculation (T2), and three (T3), five (T4), seven (T5), and ten (T6) days after inoculation.

\section{DISCUSSION}

\section{White blood cell counts}

Several studies suggest that white blood cell count is a sensitive indicator of acute inflammatory disease. In the present study, the initial decrease in WBC count at T2 may have been caused by the cytopathic effect of Salmonella Gallinarum lipopolysaccharides (LPS) on poultry leukocytes during the initial phases of the infection, causing cell lysis. In studies using a mixture of heterophils and Salmonella Typhimurium, Lam \& Munn (2002) detected changes in heterophil morphology and fast disappearance of that cell type, suggesting that the contact with LPS caused heterophil degranulation.

In $\mathrm{G} 1$, the evident leukocytosis detected at T3 and T4 coincided with the manifestation of characteristic clinical signs (apathy, dehydration, anorexia, and bloody diarrhea). Berchieri Jr. (2000) suggests that there is leukocytosis because, during the acute phase of fowl typhoid, there is a fast multiplication of Salmonella Gallinarum inside the phagocytes, causing cell lysis and release of the bacterium into the extracellular compartment. This stimulates a strong immune response and induces a type of antigen-antibody reaction that is responsible for the clinical signs. At the same time, the possible presence of the bacterium in target organs, such as the liver, spleen, kidneys, thymus, and heart, may stimulate the production and release of leukocytes into the blood stream. 
Garcia KO, Berchieri-Júnior A, Santana AM, Freitas-Neto OC, Fagliari JJ

The leukocytosis detected at T4 was characterized by an increase in lymphocyte and heterophil counts; the higher increase in heterophil count caused the inversion of the heterophil:lymphocyte ratio (Table 1 and Figure 1). That inversion may be explained by the fact that heterophils are particularly important in young birds, because their specific immune response, based on lymphocytes, is still immature. In this case, the high heterophil count may be due to the recruitment of mediators by new cells and also to the migration of the circulating heterophils to the area of the lesion, with the presence of young heterophils in the blood. In a study with experimental infection with Salmonella Gallinarum of 20-day-old broiler chickens, an increase in leukocyte counts was verified, particularly of heterophils relative to lymphocytes (Cardoso et al., 2003); the appearance of young cells in the blood stream of the infected birds, with maximum value at 11 days after inoculation, was also observed. The authors also state that these young cells probably have a heterophylic lineage, and in this case, there is a strong medullar demand which is typical of a bacterial infection. Other authors studying Salmonella Gallinarum experimental infections also observed leukocytosis and heterophilia (Assoku et al., 1970; Allan \& Duffs, 1971; Kokosharov, 1998; Freitas Neto et al., 2007), with an increase in the percentage of mielocytes during infection (Kokosharov, 1998).

After intense leukocyte activity and appearance of the characteristic clinical signs between T3 and T4, 21 birds died between T4 and T5. This indicates that the birds were unable to cope with infection, as demonstrated by the sudden decrease in leukocytes at $\mathrm{T} 5$ in $\mathrm{G} 1$ birds. This decrease may have been caused by the previous excessive recruiting of these cells to eliminate the bacterium, depleting the organs responsible for their production and storage, and rendering them incapable of producing enough new cells to control the infection.

Leukocyte count increase was less evident in G2 as compared to G1; it occurred later (T5), and was less intense (Table 1 and Figure 1). That is also reflected in the number of deaths, with 21 dead birds in in $\mathrm{G} 1$ and only nine in $\mathrm{G} 2$. The mild infection in $\mathrm{G} 2$ allowed some birds to survive, and, at T6, leukocyte counts remained stable, with an inversion, however, of the heterophil:lymphocyte ratio (Table 1 and Figure 1). As only two out of the 11 remaining birds died after the leukocytosis peak, this inversion may indicate that the birds were recovering.
Experimental infection of commercial layers using a Salmonella enterica serovar Gallinarum strain: Leukogram and serum acute-phase protein concentrations

\section{Serum Proteins}

The initial phase of the inflammatory reaction induced by infection involves the release of acutephase proteins (Gruys et al., 1994).

The results obtained in $\mathrm{G} 1$ and in $\mathrm{G} 2$ indicate that the serum levels of positive acute-phase ceruloplasmin, hemopexin, and haptoglobin proteins and negative acute-phase transferrin protein increased and decreased, respectively, during the course of the infection, probably due to the tissue lesions caused by the bacterium. Similar results were reported by Fagliari et al. (2008) in horses with acute abdomen. In a study on serum proteins of broilers of different ages, Silva et al. (2007) found a decrease in serum acute-phase proteins at 21 days of age and, according to the authors, this fact can be explained due to the birds' high protein requirements for growth. The decrease in the concentrations of the positive acute-phase proteins and the increase in transferrin levels during the most advanced phases of the infection in $\mathrm{G} 2$ birds can be considered prognostic or recovery indicators.

IgA is the main immunoglobulin that acts in the intestinal epithelium, reducing bacterial colonization. The penetration of Salmonella in the intestinal epithelium is mediated by type-III secretion system, present in Salmonella pathogenicity islands 1 and 2 (SPI1 and SPI-2) (Jones et al., 2001). According to these authors, the proteins secreted by that system interact with the epithelial cells, stimulating the production of pro-inflammatory cytokines (IL-4 and IL-6), aiding the infiltration of polymorphonuclear cells and inducing IgA production, which is an extremely important intestinal inflammatory response for the control of systemic infection. $\lg A$ is secreted in the mucous membrane of the oviduct, and then absorbed by the intestinal mucous membrane of the young birds specially during the first hours of life (Loeken \& Roth, 1983). This explains why, in the present study, the highest IgA concentrations in the infected groups were verified before the infection. At $T 2, \lg$ A serum level decreased and remained stable during the entire course of the infection, presenting similar values as those of the control group. This fact may be explained by the weak initial intestinal immune response induced by Salmonella Gallinarum. This can probably be due to the absence of flagellum on the surface of this bacterium, as this structure is a powerful stimulus for cytokines production (Wyant et al., 1999). It can also be due to a mutation in invH, one of the genes that controls the secretion of the type-III system (Altmeyer et al., 1993). It must be noted that low IgA response in the mucosa in face of an infection may 
result in stronger pathogenicity, and consequently, in high mortality in field cases of fowl tiphoid, as also recorded in the present study. The damage to the barrier of the intestinal mucosa predisposes to systemic infection and consequently, to typical tissue lesions, especially in the liver, spleen, and heart (Berchieri Jr., 2000).

Good protection against Salmonella requires as much immunity mediated by $T$ cells as humoral immunity (Berchieri Jr., 2000). Therefore, in systemic Salmonella infections, the humoral response, characterized by high IgG levels, does not eliminate the bacterium from the body if there is no cellular immune response; it is essential for the extracellular bacterial destruction process. The increase in IgG serum levels, as verified in the present study during the infection, demonstrates the importance of this immunoglobulin in the elimination of the microorganism through opsonization and complement fixation, promoting the phagocytosis of the bacterium.

In conclusion, the most significant changes in the present study were observed in G1 birds, which received a higher concentration of Salmonella Gallinarum; in other words, these birds were more susceptible to the infection as compared to G2 birds. The increase in heterophil and lymphocyte counts was one of the most evident changes in the leukogram of G1 and G2 birds, with an inversion of the heterophil:lymphocyte ratio, typical Salmonella Gallinarum infections in young layers. The main changes in the serum protein profile were an increase in the acute-phase proteins ceruloplasmin, haptoglobin, and hemopexin, and a decrease in transferrin levels. In relation to immunoglobulin concentrations, there was an increase in $\lg G$ and mild variation in $\lg A$ level during the course of the infection. The results of the present study, therefore, may aid the understanding of leukocyte kinetics, as well as acute-phase protein and immunoglobulin changes that happen during Salmonella Gallinarum experimental infection, and, consequently, the understanding of the pathophysiology of fowl typhoid.

\section{REFERENCES}

Allan D, Duffs WP. The immunophatology in fowls (Gallus domesticus) of acute and subacute Salmonella Gallinarum infection. Research in Veterinary Science 1971; 12:140-151.

Altmeyer RM, McNern JK, Bossio JC, Rosenshine I, Finlay BB, Galan JE. Cloning and molecular characterisation of a gene involved in Salmonella adherence and invasion of cultured epithelial cells. Molecular Microbiology 1993; 7:89-98.
Assoku RK, Penhale WJ, Buxton A. Haematological changes in acute experimental Salmonella Gallinarum infection in chickens. Journal of Comparative Pathology 1970; 80:473-485.

Berchieri Jr A. Salmoneloses aviárias. In: Berchieri Jr A, Macari M, editores. Doenças das aves. Campinas, Facta; 2000. p. 185-196.

Berchieri Jr A, Murphy A, Marston K, Barrow PA. Observations on the persistence and vertical transmission of Salmonella enterica serovars Gallinarum and Pullorum in chickens: effect of bacterial and host genetic background. Avian Pathology 2001; 30:221-231.

Cardoso AL, Tessari EN, Castro AG. Estudo hematológico em aves inoculadas com Salmonella Gallinarum. Arquivos do Instituto Biológico 2003; 70(1):35-42.

Fagliari JJ, Silva SL, Silva PC, Pereira GT. Leucograma e teores plasmáticos de proteínas de fase aguda de eqüinos portadores de abdômen agudo e submetidos à laparotomia. Arquivo Brasileiro de Medicina Veterinária e Zootecnia 2008; 60:322-328.

Freitas Neto OC, Arroyave WH, Alessi AC, Fagliari JJ, Berchieri Jr A. Salmonella Gallinarum: Clinical, anatomophatological and haematological studies. Brazilian Journal of Poultry Science 2007; 9:133-141

Gruys E, Obwolo MJ, Toussaint MJM. Diagnostic significance of the major acute phase proteins in veterinary clinical chemistry: a review. The Veterinary Bulletin 1994; 64:1009-1018.

Jones MA, Wigley P, Kerrie L, Page L, Scott D, Barrow PA. Salmonella enterica serovar Gallinarum requires the Salmonella pathogenicity island 2 type III secretion system but not the Salmonella pathogenicity island 1 type III secretion system for virulence in chickens. Infection and Immunity 2001; 69:5471-5476.

Kokosharov T. Changes in the white blood cells and specific phagocytosis in chicken with experimental acute fowl typhoid. Veterinarski arhiv 1998; 68:33-38.

Lam KM, Munn RJ. The cytolytic effects of Salmonella enterica serovar Typhimurium on chicken heterophils. Avian Pathology 2002; 31:277-283

Loeken MR, Roth TF. Analysis of maternal IgG subpopulations which are transported into the chicken oocyte. Immunology 1983; 49:21-28.

Lucas AM, Jamroz C. Atlas of avian hematology [monograph]. Washington: U.S. Department of Agriculture; 1961.

Natt MP, Herrick CA. A new blood diluent for counting the erytrocytes and leucocytes of the chicken. Poultry Science 1952; 31:735-738

Oliveira GH, Fernandez AC, Berchieri Jr A. Experimental infection of laying hens with Salmonella enterica serovar Gallinarum. Brazilian Journal of Microbiology 2005; 36:51-56.

Silva PRL, Freitas Neto OC, Laurentiz AC, Junqueira OM, Fagliari JJ. blood serum components and serum protein test of Hybro-PG broilers of different ages. Brazilian Journal of Poultry Science 2007; 9:213-216 
Garcia KO, Berchieri-Júnior A, Santana AM, Freitas-Neto OC, Fagliari JJ
Experimental infection of commercial layers using a Salmonella enterica serovar Gallinarum strain: Leukogram and serum acute-phase protein concentrations

Weber K, Osborn M. The reliability of molecular weight determinations by dodecyl sulfate-polyacrylamide gel electrophoresis. Journal of Biology Chemical 1969; 214:4406-4412.

Wyant TL, Tanner MK, Stein MB. Salmonella typhi flagella are potent inducers of proinflammatory cytokine secretion by human monocytes. Infection and Immunity 1999; 67:3619-3624.

Zancan FT, Berchieri Jr AB, Fernandes SA, Gama NMSQ. Salmonella investigation in transport boxes of day-old birds. Brazilian Journal of Microbiology 2000; 31:230-232. 